Tér és Társadalom 14. évf. 2000/2-3. 109-117. p.

Tér és Társadalom

XIV. évf. 2000

2-3: 109-117

\title{
A LOGISZTIKA ÉS SZEREPE A REGIONÁLIS FEJLÖDÉSBEN
}

\author{
(Logistics and Its Role in Regional Development) \\ TÓTH GÉZA
}

\section{Bevezetés}

A regionális tudomány jelentős változásokon ment keresztül az utóbbi évtizedekben. A területfejlesztésnek-területi tervezésnek mint a regionális tudomány alkalmazásának fontossága a fordista időszak óta nem csökkent, bár a gazdasági válságok gyakran felhívták a figyelmet arra, hogy folyamatos fejlődése elkerülhetetlen a többi tudománnyal párhuzamosan, s a területi fejlödés minden aspektusára adekvált válaszokat kell adnia, ezzel is bizonyítva létjogosultságát. Nem feledkezhetünk meg a jövőben a globalizált világ tendenciáiból következő új térgazdaságról (Benko 1999), melynek hatásai a rendszerváltás utáni recesszió következtében meggyengült magyar gazdaságot váratlanul érték, és sokáig nem voltak ismertek. A posztfordista gazdaság szereplőinek kapcsolatait olyan ủj tendenciák jellemzik, amelyeket a kutatók illetve a döntéshozók nem kerülhetnek meg a jövőben. Véleményünk szerint ilyen jelentôsége van az anyagmozgatás-energiaáramlás új szemléletének, a logisztikának, melynek csupán egy aspektusát vizsgáltuk: a területi folyamatokban játszott szerepét.

\section{A logisztika fogalma}

A logisztika szó görög eredetü (logo = gondolkodni, logos = értelem, logostikos = logikusan gondolkodni); bár egyes szerzők szerint kapcsolata van a katonai szállásmester francia nevével, míg mások latin eredetünek tartják és matematikai logikával végzendô cselekvésnek vélik.

A fogalom először a hadseregben jelent meg. A NATO szabályzat szerint a logisztika: szükségletek, termelékenység, hely és idő előzetes tervezése és összhangba hozása, a fö eröforrások elosztása.

A rendszerelvü megfogalmazás szerint a logisztika tulajdonképpen anyag- és energiaáramlás ill. a hozzá kapcsolódó információáramlás integrált rendszere, melynek fontos része a tervezés és az elökészítés, valamint egy globális stratégia kialakítása.

A logisztika tehát egyrészt egyfajta szemléletmód, másrészt egy módszer, mely biztosítja, hogy a feladatok a beszerzéstől az áru elosztásáig, értékesítéséig egy integrált rendszert alkossanak, amelyben az anyag, az információ és az értékáramlás egészének optimuma valósul meg. 
A logisztika feladata az ún. „5M" meghatározásban adható meg (Pfohl 1985):

- a megfelelö anyag

- a megfelelö idöben

- a megfelelö mennyiségben és minőségben

- a megfelelö helyen

- a megfelelö költségek mellett álljon rendelkezésre.

\section{A logisztika szerepe a területfejlesztésben}

Alapvető fejlesztési dilemma előtt állnak a nemzetállamok: már fejlödő régióik nemzetközi versenyképességét segitsék elö, vagy az országaikon belüli, lemaradó térségek felzárkózását segítsék-e. A befolyásoló tényezök vizsgálatánál a hazai és az Uniós csatlakozásunkhoz kapcsolódó szempontjainkat együttesen kell kezelnünk. Az állami fejlesztési, szervezeti átalakulásban, társadalmi, szociális döntésekben nagy a szerepe az EU irányelveknek. Emellett nagy a jelentősége a minőségbiztosításban $(\mathrm{TQM})^{1}$, vámszabályok módosulásában és a munkaerö szabad áramlásában megjelenő tendenciáknak is. Így ezek a változások azt hozzák magukkal, hogy olyan integrált ellátási láncokban kell gondolkodnunk, melyek a régiók kialakulása következtében térbeli integrációt is eredményeznek, ezért célszerú globális logisztikai szemléletről beszélnünk. Ebben pedig több olyan állami feladat jelenik meg, ahol fokozott logisztikai szerepvállalásra van szükség. A szerepvállalás tényezői lesznek:

- Logisztikai Szolgáltató Központok (LSZK) létrehozása,

- korridorok létrehozása $(\mathrm{TEN})^{2}$,

- városi (city) logisztika megjelenésének problémái.

Az állami szerepvállalásban nem hagyható figyelmen kívül, hogy az egyes tényezöket integráltan kell kiépíteni, s a koordinációt az üzemeltetés során végig elötérbe kell helyezni a gazdasági érdekek figyelembevételével.

A Logisztikai Szolgáltató Központok definíciója, szerepe, a központok és a gazdasági környezet közötti kölcsönhatás

Az LSZK-k közlekedési szempontból kedvező helyre telepített, a termelő és a felhasználó közötti logisztikai és más jellegü szolgáltatást biztosító, anyag-energia ill. információáramlási kapcsolódási pontok.

Többnyire egy-egy régió ellátási-elosztási feladatainak végrehajtását segítik elő a rakodás, szállítás és a termeléshez szorosan nem kapcsolódó, általában értékhozzáadó tevékenységek ellátásával, átvállalásával. Egyes központok csupán az adott ország határain belül végeznek ellátást, disztribúciót, míg más logisztikai központok részei egy nemzetközi ellátó, elosztó hálózatnak. LSZK-t létrehozhat egy-egy cég a saját áruinak tárolására-szétosztására, de megvalósulhat vállalkozási formában is. Ebben az esetben az ipari parkhoz hasonlóan a vállalkozó ingatlant biztosít a majdani logisztikai szolgáltatók számára. 
A központ földrajzi elhelyezkedés szempontjából lehet a termelési hely vagy a piac közelébe telepített. Az LSZK-k általában alkalmasak kombinált forgalom lebonyolítására, azaz több közlekedési alágazat közötti kapcsolat megteremtését szolgálják. Az LSZK és a gazdaság között szoros kölcsönhatás áll fenn. Ebböl az következik, hogy LSZK-t olyan helyen célszerü létesíteni, ahol a makro- és mikroszintủ gazdasági tényezök ezt indokolják, s fejletlen területen nem vagy csak töredékesen tölti be szerepét.

Magyarországi viszonylatban viszont a tervekben megjelenő LSZK-k esetén nem mindig ez a helyzet (pl. Záhony, ahol egy gazdaságilag az országos átlaghoz képest fejletlen területen a nemzetközi folyamatokhoz kapcsolódó logisztikai központot próbálnak kialakítani), ezért a területi fejlődés más spektrumában is érdemes bemutatni kapcsolatrendszerüket.

A vasúti fövonalak mentén elhelyezkedö térségek, s különösen a csomópontok jelentős helyzeti elönyre tettek szert a távolabbi, s ennek következtében egyre inkább leépülő térségekkel szemben. Ezek gazdasági viszonyait a csökkenö határköltségek jelentősen befolyásolták, $\mathrm{s}$ versenyképességük leromlott, majd megindult a munkaerő elvándorlása, így periférikus helyzetük stabilizálódott. A közlekedésföldrajzi csomópontban elhelyezett LSZK multimodális rendszerei lévén területi kiegyenlitést visz, illetve vihet végbe oly módon, hogy az alágazatok közötti optimális kapcsolatot megtalálva elösegíti a korábban kedvezötlen helyzetủ térségek piacrajutását, $\mathrm{s}$ ezzel tulajdonképpen jelentös területek ,feltárását" ${ }^{\text {”3 }}$ végzi elősegítve a régiók integrálódását a nagyobb hálózatokba, illetve a meglévő szállítási kapacitások optimális kihasználását. Ezzel az LSZK képes lehet a korridor gazdasági dinamizmusából adódó vonzereje révén az országos átlagot meghaladó mértékü sávos fejlödést ellensúlyozni, s a termelési tényezők túlzott koncentrációját megakadályozni.

A közlekedési „feltárás” mellett további tényezöként a hozzákötödés is megfigyelhetö az LSZK és környezete vonatkozásában. Ennek következtében a kapcsolatok térbeli intenzifikálása lesz megfigyelhetö (a ,just in time" elv bármely típusának megvalósítása egyenes következményeként) megteremtve annak a lehetöségét, hogy a fejlödési impulzusok (innovációk) a centrum helyzetben levö LSZK-ból annak vonzáskörzetébe áttevődjenek.

Így olyan, eddig hiányzó gazdasági alágazatok telepedhetnek meg, amelyek igénylik az áramlatokhoz való igazodást. Nem szabad elfelejtkezni arról sem, hogy az LSZK multiplikátorként hoz, illetve hozhat maga után további változásokat a pillanatnyi gazdasági trendek, struktúrák tükrében. Így a nemzetközi láncolatokba integrált LSZK-k feladatköre nem lehet egyoldalúan nemzetközi irányú, fenn kell tartani a helyi illetve regionális vonzatokat is, még ha azok volumene jelentösen kisebb az elöbb említettektöl. Gyors és folyamatos alkalmazkodásra van szükség az aktuális területi folyamatokhoz, s szolgáltatásaikat a mindenkori piachoz kell igazítaniuk, még akár azt is figyelembe véve, hogy lokális vagy regionális léptékben a multimodális megoldások nem minden esetben gazdaságosak. 


\section{LSZK általános modellje és föbb típusai}

Gazdaságossági szempontok indokolták és indokolják a raktárláncolatok fokozatos leépítését. Megnövekedett az igény a készletszintek csökkentésére, és kezdtek kialakulni a raktárkészlet nélküli ,just in time"4 módszerrel történő beszállitásra szolgáló eljárások, technológiai megoldások. Megjelentek a kihelyezett raktárak, amelyek elsősorban a felhasználótól vállalták át a raktározási feladatokat, később pedig a beszállító ilyen jellegủ tevékenységét is átvették. Ezek képezik a Logisztikai Szolgáltató Központok csíráját.

\section{LSZK típusai}

A legkevesebb szolgáltatást az Áruelosztó Központok biztosítják. Feladatuk elsősorban az árugyüjtés-áruelosztás. Létrejöhet több önálló szervezet egyesülésével, vagy a multinacionális vállalatok saját értékesítési részét képezi.

Az Áruforgalmi Központok általában több közlekedési alágazat kapcsolódási pontjai (közút-vasút-víziút), a távolsági és helyi szállítás összekötő elemei; anyagés információáramlási kapcsolódási központok. Az áruforgalmi központot közlekedési, szállítmányozási, raktározási stb. szolgáltatást nyújtó cégek üzemeltetik. Az üzemeltetők közösen használnak egyes létesítményeket, infrastruktúrát, szolgáltatást. Legföbb különbsége az LSZK-tól, hogy még nem valósul meg a „fordítókorong" jelleg.

$L S Z K^{6}$ - Áruforgalmi Központból funkcióbövüléssel alakulnak ki, s több szolgáltatást képesek nyújtani. Az LSZK-ban mind a hagyományos kocsirakományú, mind pedig a kombinált szállítmányok átrakása, rakodása, raktározása megtörténik (RO$\mathrm{LA}^{7}, \mathrm{RO}-\mathrm{RO}^{8}$ ). Így tehát megvalósul a ,fordítókorong” jelleg.

\section{Logisztikai központ létesitésének térségfejlesztö, pozitiv hatásai}

Saját kutatásaink és a szakirodalom ide vonatkozó tézisei alapján (Knoll 1999) a következö térségfejlesztỏ hatásokkal lehet számolni:

- A régióra gyakorolt hatások

A körzet általános gazdasági fellendülése, fejlödése várható. Az áruellátás javulását vonja maga után, és a terület gazdaságilag felértékelödik.

- A közlekedésre gyakorolt hatások

Elősegíti a közlekedési alágazatok közötti optimális munkamegosztás kialakulását, kombinált szállítás elterjedését, a környezetbarát közlekedési alágazatok (RO-LA, RO-RO) általánossá tételét.

- A településre gyakorolt közvetlen hatások

Várhatóan külföldi szakmai befektetőket vonz a térségbe, mind termelö, mind szolgáltató vállalatokat, ezáltal is munkalehetöséget biztosít.

- A régióban müködö vállalatokra gyakorolt hatások

A termelő vállalatok korábban gazdaságtalanul, vagy kis hatékonysággal végzett logisztikai tevékenységeit részben vagy egészben átadhatják a logisztikai szolgáltató központnak (ún. „make or buy” "öntés), s így csak a termelésre koncent- 
rálhatnak. Egy helyen vehetnek igénybe bizonyos szolgáltatásokat, s így jelentös többletköltségtől szabadulhatnak meg, ugyanis egy termelö vállalat összköltségén belül a logisztikai feladatok ellátását biztosító müveletek költsége 4,4-32\% között mozog (Halászné Sípos 1998). Jelentősen csökkenthető a logisztikai szolgáltatást igénybe vevő vállalatoknál a tárolt készletek mennyisége, a felszabadult hely termelésre felhasználható. Jelentősen nő a vállalatok versenyképessége a gyorsabb, pontosabb vevőkiszolgálásnak köszönhetően.

- A szállitó és szolgáltató vállalatokra gyakorolt hatások

Lehetöség nyílik a vállalatok közötti együttmüködésre, mivel közösen vehetik igénybe az LSZK infrastruktúráját. A szállitási kapacitások jobban kihasználhatók, a gazdaságtalan szállítások elkerülhetök lesznek. Gazdaságosan gépesíthetők ill. automatizálhatók az anyagmozgatási, raktározási és disztribúciós folyamatok, központosíthatók bizonyos vám és vámjellegü feladatok, pénzügyi, banki és postai szolgáltatások.

További pozitív hatások:

- az önkormányzati adóbevétel növekszik,

- csökken a lakott terület áruszállítási terhelése,

- a körzet áruellátási szintje növekszik,

- csökken a környezetszennyezés,

- javul a vevőkiszolgálás ${ }^{10}$.

\section{Az Európai Unió irányelvei és megállapodásai a közlekedési ágazatok közötti megoszlással kapcsolatban}

Magyarország az Európai Unió felé orientálódván kénytelen átvenni annak irányelveit $^{11}$, s alkalmazkodni az ottani trendekhez (Knoll 1999). Ezek a közlekedés illetve a logisztika tekintetében a következök:

1) Az Európai Bizottság (EC) 1998-ban létrehozta a TRILOG ${ }^{12}$ projektet, amely logisztikai ill. ezen belül korszerü közlekedési rendszerek terjesztését szorgalmazza.

2) A korábbinál sokkal következetesebben érvényesíteni kell a környezet megóvásának szempontjait a fenntartható fejlódés elvének figyelembevételével. Támogatandó a vasúti s ezen belül a kombinált szállítás illetve a belvízi szállítás. A modal split ${ }^{13}$ ezirányú változtatását nemcsak környezeti, hanem a forgalmi szempontok is indokolják, a forgalomnövekmény legnagyobb részét a túlzsúfolt közutakról át kell terelni a kapacitásfelesleggel rendelkező vasutakra és vízi utakra.

3) A szállítási-közlekedési útirányok Magyarországon nemcsak a korábbi nyugatkelet irányt követik, hanem növekszik az észak-dél kapcsolatok jelentősége is.

4) Figyelembe kell venni az EU által kitüzött és nemzetközileg kiépítendő Transzeurópa útvonalakat (TEN) ${ }^{14}$. Ezen belül minket a IV., V., VII. és X. korridor érint. 
5) A TEN kibővítését jelentik az 1999 elején előkészítés alatt álló TINA projekt ${ }^{15}$ és a közlekedéshálózat fejlesztési tervei.

6) A nagyvárosokat elkerülö autópályákat (körgyürük) ki kell építeni.

7) A korábbi gazdasági struktúrák változásával, eltolódásával új ipari, kereskedelmi régiók alakulnak. Az itt megjelenő feladatok lebonyolitására Logisztikai Szolgáltató Központok létesülnek. Ehhez kapcsolódóan jelentös infrastruktúra épül ki (informatika, közüzemi hálózatok stb.).

8) A vámelöírások radikálisan csökkennek ill. változnak, mindez közvetve a határátkelöhelyek átépítését, esetleg új kamion-terminálok kialakítását is igényelheti.

9) A nemzetközi forgalomban rövidesen már csak az ISO szabványelöírások szerinti, minöségbiztosítással rendelkező cégek müködhetnek.

10) NATO csatlakozásunk után bizonyos nemzetközi útvonalak kiemelt prioritást kaptak, így ezek kiépítése és fejlesztése a polgári törekvésekkel összhangban kell, hogy megtörténjék.

\section{A Transzeurópai Hálózatok megjelenése}

A kilencvenes években az EU és a társult országok között megélénkült kereskedelmi tevékenységek következtében növekszik a tőkeexport is. Az Európai Uniós országokból származó befektetések elsősorban a nagyvárosokba és a gazdaságilag erösebb régiókba vándorolnak, ezzel tovább erösítik a csatlakozni akaró országokban a területi egyenlőtlenségeket. Ezen országok jövőbeli fejlődése bizonytalan, mivel a növekedési tényezök és a szerkezetváltás lehetősége az egyes térségekben igen eltérö mértékben van jelen. A fövárosok és a környezö központi térségek elönyben vannak, mivel a külföldi befektetések itt koncentrálódnak. Hosszú távon azonban a tranzittengelyek mentén fek̋̋ térségek is profitálhatnak a fejlödésböl. Ehhez viszont szükség van a közlekedési tengelyek, korridorok (TEN) kiépítésére.

A TEN előmozdítja a regionális gazdasági fejlödést, csökkenti a régiók közötti különbségeket.

A TEN-nel szembeni elvárások:

- a periférikus régiók helyzetének javítása,

- a közlekedési infrastruktúra közel egyenlö minőségü elérhetőségének biztositása,

- a „környezetbarát” közlekedési hálózat kialakítása a közúti forgalom egy részének vasútra terelésével, s az „értelmetlen” mobilitás megakadályozása, a felesleges közlekedés elkerülése.

\section{Periféria probléma}

$\mathrm{Az}$ EU területpolitikai törekvéseinek középpontjában a periférikus térségek felzárkóztatása áll. E törekvés egyik oka, hogy Európa a globális versenyben nem mondhat le a perifériáiról ill. az ottani erőforrásokról. Emellett Európa sokszínüségének, mint relevanciájában növekvő értéknek a fenntartására is szükség van. 
Periférikus területnek közlekedési szempontból azt a területet értjük, amelyből az agglomeráció centruma 3 óra oda-vissza utazással érhetó el. A periférikus térségek fejlesztésekor sokan várják el e nagy beruházásoktól, hogy jelentősen növeljék a foglalkoztatottságot, s csökkentsék a munkanélküliséget. Ezt az igényt viszont a korridorok fejlesztése nem tudja kielégíteni. A fejlettségbeli különbségek elmélyülnek, $\mathrm{s}$ a térkapcsolatok végső esetben dinamikus városok - kiürülö perifériák viszonylatban jelentkezhetnek. Ennek egyik oka az, hogy a folyosók üzemeltetésének kicsi az élőmunka igénye. A folyosók növekedést elősegíto hatása elsősorban az összekötött nagyvárosokban érvényesül (vagyis a fentebb bemutatott elvárás csak részben teljesül), bár a periférikus térségek jobb közlekedési infrastruktúrája jelentős beruházást elősegitő tényezöt jelent (Erdösi 1998; 1999).

A periférikus helyzetből következő hátrányok orvoslásánál a következő célokból kell kiindulni:

1) Csökkenteni a földrajzi elszigeteltséget a megközelíthetőség javításával,

2) javítani a kommunikációs és közlekedési infrastruktúrát,

3) az endogén fejlesztést ösztönözni, föleg helyi természeti és emberi erőforrások révén,

4) a gazdasági szerkezet diverzifikálását segíteni,

5) meg kell óvni az ökoszisztémákat, amelyek éppen az elszigeteltség miatt maradtak fenn,

6) javítani kell az életkörülményeket,

7) az információs infrastruktúra és a telekommunikációs hálózatok fejlesztése mellett a $\mathrm{K}+\mathrm{F}$ tevékenységek telepítése kiemelten szükséges.

\section{A CITY-logisztika megjelenése}

A város és a városi közlekedés jelentös fejlödésen ment keresztül. A városi közlekedési rendszer elemzése és értékelése, a városi forgalmi felvételek legkörültekintőbb vizsgálata elkerülhetetlen a városi közlekedés rendszerelvú vizsgálata során. $\mathrm{Az}$ elemzés eredményeként a városi forgalom tervezésének modelljei és modellparaméterei alakulnak ki, melyek a városi hálózattervezés alapelvei.

Fontos cél a lakóterületek primer hálózattal való ellátása, a hálózati elemek méretezése, különböző irányítású csomópontok forgalomtechnikai méretezése, jelzéstervek kialakítása, ezzel a felesleges és környezetszennyezö forgalmat minimálisra lehet csökkenteni. Hasonló a jelentősége a tömegközlekedési hálózat és rendszer térbeli-időbeli méretezésének és tervezésének, $s$ a tömegközlekedés beillesztésének a városi forgalom egészébe. Meg kell szervezni a gyalogosforgalom térbeli-időbeli lebonyolódását, gyalogos létesítményeket ill. hálózatokat. Mai városaink egyik legfontosabb problémája a városközpont közlekedési zsúfoltsága, melyre megoldási lehetőségeket kell találni fïgyelembe véve a gazdasági ill. egészségügyi-környezetvédelmi szempontokat, $\mathrm{s}$ amennyire lehetséges csökkenteni a városi forgalmat. 


\section{Összegzés}

A jövő Magyarországa épitésében tehát az új regionális folyamatok új megoldásokat követelnek meg. E megoldásoknak figyelembe kell venni az eurologisztikai folyamatokat a területi fejlödés további aspektusaival párhuzamosan. Így optimális lehet az egyes régiók pozíciója mind a regionális kapcsolatokban, mind az európai versenyben.

\section{Jegyzetek}

${ }^{1}$ Total Quality Management

2 Transeuropean Network: A Transzeurópai Hálózatok a vonalas infrastruktúra olyan európai léptékú integrált rendszere, amelybe a közlekedési, távközlési és energiaszállítási nemzetközi vonalak egyaránt beletartoznak.

${ }^{3}$ A feltárás kifejezés jelen esetben a nemzetközi áramlatokba való beintegrálódás szempontjából értendő.

${ }^{4}$ Éppen időben történô szállítás.

${ }^{5}$ A kơzlekedési alágazatok igény szerinti váltása.

${ }^{6}$ Magyarországon valamennyi logisztikával foglalkozó központot logisztikai központnak neveznek, mely egy helytelen kifejezés, hiszen valójában csak a legtöbb szolgáltatást biztosító, legutolsónak bemutatott központ nevezhetö annak.

${ }^{7}$ Rollende Landstrasse - gördülö országút (közút-vasút)

${ }^{8}$ Roll on - Roll off (közút-víziút)

${ }^{9}$ Gyárts vagy gyártass!

10 customer service

11 Az Európai Uniónak nines ugyan elfogadott közös közlekedési politikája, de megfogalmazhatók bizonyos elvek, amelyeket az országoknak magukévá kell tenni.

12 European Task Force of the Trilateral Logistics

${ }^{13}$ Alágazati szerkezet

14 A TEN irányelvekröl 1989-ben az EK csủcsértekezlet döntött, de a kidolgozott irányelveket a Közlekedési Miniszterek Konferenciája csak 1995-ben fogadta el, s azok 1996-ban léptek életbe. A csatlakozni vágyó országok kapcsolódásáról 1997-ben, Helsinkiben, a III. Páneurópai Közlekedési értekezlet döntött kijelölvén a „páneurópai korridorokat”.

${ }^{15}$ Ennek a programnak a neve: Közlekedési Infrastruktúra lgények Felmérése ill. az angol megfelebjéböl rövidítve TINA (Transport Infrastructure Needs Assesment). A TINA munkáját egy Bécsben sž́kelö titkárság irányítja, és az országok három munkacsoportra oszlottak, földrajzi elhelyezkedés szrint. Magyarország a Közép- és Kelet-európai Munkacsoport tagja. A munkacsoportokról elmondható, hogy jelenlegi EU-tagországok képviselöi is részt vesznek benne, sőt, ők azok vezetöi is. 1998 augusztusában készült el az első TINA-jelentés.

\section{Irodalom}

Benko, G. (1999) A regionális tudomány. Pécs-Budapest, Dialóg Campus Kiadó.

Chikán A. (1998) Anyagi folyamatok és készletek - a logisztikai rendszer. Vállalatgazdaságtan. Budapest, Aula. 327-361. o.

Chikán A. (1999) Az értékteremtö folyamatok menedzsmentje. Budapest, Aula.

Enyedi Gy. (1996) Regionális folyamatok Magyarországon az atmenet idószakában. Budapest, Hilscher Rezsö Szociálpolitikai Egyesület.

Erdősi F. (1998) A transzeurópai hálózatok hatása a területi fejlódésre. - Tér és Társadalom. 3. 27-50. o.

Erdősi F. (1999) A transz és páneurópai hálózatok. Magyarország az európai regionális együttmüködésben. Budapest, MTA RKK-Magyar Külügyi Intézet. 51-75. o.

Halászné Sípos E. (1998) Logisztika: szolgáltatók, versenyképesség. Budapest. 
Horváth Gy. (1998) Európai regionális politika. Budapest-Pécs, Dialóg Campus Kiadó.

Knoll I. (1999) Logisztika a 21. Században: Profitnövekedés logisztikai eszközökkel. Budapest.

Logisztikai management. (1996) TDQM-PHARE.

Logisztikai Szolgáltató Központok makrogazdasági szerepe a mai Magyarországon. (1993) Budapest, Logisztikai Fejlesztési Központ.

Pfohl, H. Chr. (1972) Marketing - Logistik. Berlin, Distributions Verlag.

Pfohl, H. Chr. (1985) Logistiksysteme. Berlin.

Rechnitzer J. (1998) A területi stratégiák. Budapest-Pécs, Dialóg Campus Kiadó.

Szegedi Z. (1998) Logisztika menedzsereknek. Budapest.

\section{LOGISTICS AND ITS ROLE IN REGIONAL DEVELOPMENT}

\section{GÉZA TÓTH}

Globalization sets off new tendencies in corporate systems of which serious consequences can be observed in spatial processes. Therefore it is important for a unified system of Hungarian Logistical Servicing Centres in order to connect to international flows, thereby helping more regions access to markets. In this way the favourable effects of the TRANSEUROPEAN NETWORK Systems can be utilized, especially by decreasing geographical isolation and developing accessibility. The role of logistics can be looked at from the point of view of local dimensions as well and in this way the systematic organization of the city traffic can help to minimalize the unnecessary and polluting traffic. Logistics, then has a defining role in global competition on both local and regional levels. 